\title{
ESCREVER COMO GESTO: EXPERIÊNCIA DA LINGUAGEM NA POESIA E NA FILOSOFIA
}

\author{
[ WRITING AS A GESTURE: EXPERIENCE OF LANGUAGE IN THE POETRY AND IN THE \\ PHILOSOPHY]
}

\begin{abstract}
Resumo: Resumo: Partindo do ABstract: Abstract: From the Heideggerian empreendimento heideggeriano de uma enterprise of an 'experience with language', "experiência com a linguagem", que encontra which finds in poetry the royal way, in na poesia a via régia para, nas palavras de Heidegger's words, 'to bring language as Heidegger, "trazer a linguagem, como language to language', we will seek to linguagem, à linguagem", buscaremos understand philosophy and poetry, insofar as compreender filosofia e poesia, na medida em are speeches with pretensions to the truth and to que são discursos com pretensões à verdade e à the language's exposition, as forms of speech exposição do que seja a linguagem, como characterized by the elision of the author's formas de discurso caracterizados pela elisão figure in the writing gesture itself. In this da figura do autor no gesto mesmo da escrita. search, we will come into contact with Carlos Nessa busca, tomaremos contato com a poesia Drummond's poetry and with a subtle rhetorical drummoniana e com uma sutil estratégia strategy found in Plato's dialogues, particularly retórica encontrada nos diálogos de Platão, noted by Jeanne Marie Gagnebin.
\end{abstract}

notada por particularmente Jeanne Marie KEYwORDS: Language; Writing; Truth; Gesture Gagnebin.

Palavras-chave: Linguagem; Escrita;

Verdade; Gesto

$\mathrm{E}$ m uma série de três conferências pronunciadas entre dezembro de 1957 e fevereiro de 1958, enfeixadas sob o título "A Essência da Linguagem", Martin Heidegger pretende colocar-nos ante a "possibilidade de fazer uma experiência com a linguagem" (HEIDEGGER, 2008, p. 121). Tal experiência constitui-se não na tomada de conhecimentos concernentes à linguagem e ao seu modo exterior de operação (que levamos a termo na fala). "Fazer uma experiência com algo", escreve Heidegger, "seja com uma coisa, com um ser humano, com um deus, significa que esse algo nos atropela, nos vem ao encontro, chega até nós, nos avassala e transforma". Numa experiência assim compreendida, não se apreende como a linguagem seja, mas simplesmente que ela é. Em suma, trata-se de trazer à linguagem não as coisas que ela diz (seus "referentes" no mundo), mas ela mesma, a própria linguagem.

Mas onde a linguagem como linguagem vem à palavra? Raramente, lá onde não

* Doutorando em Filosofia pela Universidade do Estado do Rio de Janeiro, UERJ. Mestrado em Filosofia pela Universidade Federal Fluminense,UFF.m@ilto: ca.rpereira@hotmail.com 
encontramos a palavra certa para dizer o que nos concerne, o que nos provoca, oprime ou entusiasma. (...) Quando se trata de trazer à linguagem algo que nunca foi dito, tudo fica na dependência de a linguagem conceder ou recusar a palavra apropriada. Um desses casos é o do poeta. Um poeta pode até mesmo chegar ao ponto de a seu modo, isto é, poeticamente, trazer à linguagem a experiência que ele faz com a linguagem (Idem, ibidem, p. 123).

Um lugar propício para que o pensamento desempenhe tal experiência, no qual possa ser trazida à palavra a própria linguagem, é o dizer poético. Heidegger busca, portanto, na escuta de um poema, a possibilidade dessa ex-periência (Er-fahrung): ser conduzido (fahren) à linguagem, como linguagem, pelo próprio poema, por aquilo que nele se diz. O poema que Heidegger elege para essa escuta, no âmbito das três conferências, é A Palavra, do poeta alemão Stefan George1x. Nesse poema trata-se, sobretudo, do aprendizado de uma renúncia, que leva o poeta à seguinte declaração, no último dístico do poema: "Triste assim eu aprendi a renunciar:/ Nenhuma coisa que seja onde a palavra faltar". Compreendendo que a linguagem predomina como o trazer à vigência, evocando, as coisas para que possam concernir ao mundo dos homens, o poeta renuncia a um determinado modo de relacionar-se com a palavra - como mero nome, signo arbitrário com o qual o poeta chama, designa e "adorna" aquilo que, previamente, dispõe-se para ele. $\mathrm{O}$ que se perde na renúncia do poeta é, portanto, uma concepção instrumental da linguagem, na qual ela estaria disponível como instrumento de expressão de coisas como "ideias" ou "sentimentos". Mas de onde proveio o aprendizado dessa renúncia? Do momento em que, ansiando por "boa travessia", isto é, por mais um encaminhamento pelo dizer que o levasse ao poema, o poeta busca na fonte do destino (a morada da deusa Norna) um nome para certa "joia delicada e rica". Seu intento, no entanto, malogra, pois a deusa não tem um nome com o qual evocá-la e com isso, a joia perde-se para o poeta ("E minha terra nunca um tesouro encontrou...", diz o verso do poema). Diante disso, o poeta reconhece que, sem a palavra, ou melhor, onde falta a palavra, nada perdura. Cumpriu-se, assim, uma experiência com a linguagem que trouxe, à linguagem (do poema), o poder mais próprio da palavra: ser aquilo que Heidegger nomeia como a con-dicção (Bedingnung) das coisas (Dinge): o dizer-se junto de palavra e coisa, no qual elas emergem e, vindo ao mundo, pertencem aos homens. Contudo, não se disse anteriormente $o$ que é a referida joia. Tudo que dela podemos afirmar até então é: ela (a joia) não é um "milagre da distância e da quimera", segundo expressão do poema, ou seja, não é um ente dado de antemão (Vorhandenheit), ao qual se compreende como previamente disponível para uma nomeação arbitrária. Também Heidegger não diz explicitamente em que consiste essa joia. Concentra-se na observação de que, a partir de seu anonimato, ou seja, de sua recusa em receber um nome, a joia ensina e sustenta o poder mais próprio de nomeação da linguagem: a convocação do mundo. A joia é seu próprio anonimato e retração, seu estar destinado ao nada.

Que esse elemento, retido na recusa de um indizível, seja chamado de "joia" (S. George), indica que nele se pensa uma riqueza peculiar: a abundância de um dom, de uma graça, daquilo que é, por favor e gratuidade, concedido. No mistério desse dom, Heidegger compreende a essência da linguagem: ela é a concessão do poder de, nomeando, evocar as coisas, sustentar o mundo e dar direção, medida à existência humana. Esse puro dom de nomear é entrevisto pelo poeta, que, no entanto, deve perdêlo e deixá-lo para chegar ao poema. Enquanto a linguagem repousar no puro dom de uma graça, o poder nomeador da linguagem permanece inominado. Não há palavra para a Palavra, a linguagem não pode dizer-se: "A palavra para dizer a palavra não se deixa encontrar em nenhum lugar em que o destino dá aos entes o presente da linguagem nomeadora e inaugural, essa que nomeia que o ente é e como o ente brilha e brota" (Idem, ibidem, p. 150). Fazer uma experiência com a linguagem: ser levado, por ela mesma, à sua essência. No pensamento de Heidegger, a via régia dessa condução, o poema, está assentado sobre um inominado, um indizível. O poema dá a dizer, isto é: 
naquilo que nele é dito, em sua saga (Sagen), o poema convoca o mundo e as coisas e chama ao homem para habitar na proximidade delas - quando está fundado sobre um não dito, um silenciado. Não por acaso Heidegger afirma que: "A linguagem fala como consonância do quieto" (Die Sprache spricht als das Geläut der Stille) (Idem, ibidem, p. 24). A palavra alemã Geläut que Heidegger aqui emprega provém do verbo alemão läuten: soar, tocar, fazer dobrar (o sino). A fala da linguagem é consoante ao soar das palavras - mas o que nela ressoa não tem som, é colhido no calmo silêncio (Stille).

\section{II}

Parece insinuar-se aqui a seguinte dificuldade quanto ao procedimento heideggeriano: se a escuta do dizer poético deve ser a via régia para "trazer a linguagem, como linguagem, à linguagem”, ela falha em seu intento, pois o próprio do poema (o poder nomear a linguagem ela mesma) resta inominado. Se o poema não pode dizer a si mesmo, então o próprio da poesia (como forma do discurso em que se realiza uma experiência com a linguagem) é um inapropriável - algo de que a poesia mesma não pode apropriar-se e levar a um dizer. Caso o dizer poético deva ser capaz de nomear a linguagem, deverá antes impor-se a paradoxal tarefa de apropriar-se do inapropriável; de nomear não uma presença, mas uma ausência. Perguntamos: o que se encontra ausente na poesia, do qual ela tenta em vão apropriar-se? Voltemos ao poema de que Heidegger se ocupa: o poema de S.George trata da própria palavra poética, é poema sobre o poema - no mesmo sentido em que, para Heidegger, Hölderlin torna-se o poeta do poeta (Dichter des Dichters), isto é, aquele cuja obra é "propriamente sustentada pela determinação poética de poetizar a própria essência da poesia" (Idem, 2013, p.44). É sobre essa determinação, inclusive, que Heidegger fundará a direção de leitura, e mesmo a escolha dos poetas com os quais trava constante diálogo, e por isso a precedência de um Hölderlin frente a "Homero ou Sófocles", "Virgílio ou Dante", "Shakespeare ou Goethe" (Idem, ibidem, p. 43) - poetas esses que nomearam os deuses, os homens e as coisas de seu mundo, como o amor, a guerra etc. Esse tipo de escolha "temática", por assim dizer, não se deve ao arbítrio do poeta em determinar os temas de sua poesia, mas possui um conteúdo histórico importante. Heidegger pensa esse conteúdo histórico, a partir de Hölderlin, como o sinal de um "tempo indigente", no qual é ainda preciso perguntar-se: "Para quê poetas?". Na conferência que porta esse título (1946), Heidegger escreve:

Ser poeta em um tempo indigente significa: cantar, tendo em atenção o vestígio dos deuses foragidos. É por isso que, no tempo da noite do mundo, o poeta diz o sagrado. (...) À essência do poeta que, em um tal tempo do mundo, é verdadeiramente poeta, pertence o fato de, para ele, de antemão e a partir da indigência do mundo, o poetar e a vocação poética se tornarem questões poéticas. Por isso, os "poetas em tempo indigente" têm de poetar a própria essência da poesia (Idem, 2012, p. 312-3).

A palavra da poesia tem de voltar-se sobre si mesma quando não pode mais nomear os deuses que se foram: eles não luzem mais na claridade do Sagrado quando vigora um "obscurecimento do mundo", "cujos processos Essenciais são: a fuga dos deuses, a destruição da terra, a massificação do homem, a primazia da mediocridade", como escreve Heidegger no curso de 1935 Introdução à Metafísica (Idem, 1999, p. 71). Trata-se aqui de um fenômeno que atinge a totalidade da abertura de horizonte de mundo da existência humana (o Dasein), não apenas restringindo mas sustando suas possibilidades de envios históricos em modos de ser, à medida que os deuses não concedem, no dizer poético, a medida da habitação humana sobre a terra, esta vê-se reduzida a mero meio de sustento e exploração, e o humano, perdendo de vista a experiência de sua fundamental mortalidade, jaz massificado como mera capacidade psicossomática de trabalho e consumo. Nesse cenário, no qual não são visíveis mais os 
acenos dos deuses, nesse tempo dito "indigente", a poesia assume a tarefa de dizer-se a si mesma, de nomear-se.

O que a escuta heideggeriana da poesia libera para o pensamento é o que resta do poema sob essa tarefa: tendo que dizer seu próprio poder de, enquanto dom, dar a ver na nomeação o mundo e as coisas que nele concernem aos homens, a poesia 112 precipita-se no silêncio - que assim surge como solo em que a linguagem deita raízes. $A$ poesia, sem os deuses, seria a experiência de um longo silêncio, o dizer(-se) a partir desse silêncio. O poeta tem de silenciar(-se) na poesia, uma vez que a partir desse silêncio a poesia experimenta a linguagem como evocação do mundo. Em momento algum Heidegger diz o que o poeta tem de silenciar na poesia. Mas em um poema que se chama Procura da poesia, Carlos Drummond de Andrade ensaia mostrar, na medida em que as palavras permitem, o que deve estar silenciado no poema:

\author{
(...) \\ Tua gota de bile, tua careta de gozo ou de dor no escuro \\ são indiferentes. \\ Nem me reveles teus sentimentos, \\ que se prevalecem do equivoco e tentam a longa viagem. \\ O que pensas ou sentes, isso ainda não é poesia \\ (...) \\ O canto não é a natureza \\ nem os homens em sociedade. \\ Para ele, chuva e noite, fadiga e esperança nada significam. \\ A poesia (não tires poesia das coisas) \\ elide sujeito e objeto.
}

(DRUMMOND, 1982, p. 156)

A poesia tem lugar em um certo eclipse da vida, ou melhor, na suspensão daquela dimensão da vida que engloba particularidades como o amor, o desejo, o sofrimento, o lugar e os outros, as perdas e os ganhos. Parece estranho que se possa afirmar que um poeta como Drummond, que não era alheio, em sua poesia, a nenhuma dessas figurações da vida, conceba o fazer poético como um alheamento do vivido. Preferimos dizer que, quando o vivido é uma mera vivência de um particular (aquela sequência vazia de eventos passíveis apenas de constituir uma biografia), ele é insuficiente para que se possa fazer uma experiência poética com a linguagem experiência na qual, ainda seguindo as indicações de Heidegger, a linguagem ela mesma vem à palavra. Quando, porém, se tem uma experiência do vivido (quer seja o amor, o desejo, o lugar, os outros etc.), no sentido mesmo de ser por ele perpassado e conduzido, o que aí se co-experimenta é a palavra: como se todo horizonte de sentido e orientação da vida (o que a atividade filosófica costuma chamar de mundo) fosse aberto pela palavra, estivesse sustentado em linguagem. Quando faz experiência da vida, o poeta co-experimenta a linguagem que permite a vida - e o poema "É minha terra/ e ainda mais do que ela. É qualquer homem/ ao meio-dia em qualquer praça. É a lanterna/ em qualquer estalagem, se ainda as há", como ele escreve na Consideração do Poema. A palavra da poesia é uma tentativa de se apoderar do vivido que, atingindo-o como vivência particular, transforma-o em experiência: comunica-o, mas ao preço de calar a sua particularidade, o sujeito que vivenciou e o objeto vivenciado (e assim a poesia "elide sujeito e objeto").

Se na poesia a palavra é vida, no poeta o vivido ganha duas tonalidades opostas: experiência e vivência ${ }^{2}$. A palavra poética é aquela que busca agarrar a vivência, mas, 
ao fazê-la, torna-a já experiência: vida comunicada, salto da particularidade do indivíduo para um sentido compartilhado. É no silenciado das meras vivências, quando a palavra delas faz experiência, que emerge a poesia. $A$ vida (no sentido das vivências particulares, ou do que poderíamos chamar de "vida do autor") é o inapropriável da poesia: aquele fundo silenciado do qual a palavra poética não consegue apropriar-se integralmente sem perverter sua idiossincrasia (de certa forma, seu idiotismo) e que, no entanto, é por meio de seu próprio silenciar-se que ela chega ao dizer.

Se as vivências, como aquela dimensão meramente biográfica da vida, devem ser silenciadas, delineia o que o poeta deve trazer à linguagem. Assim seguem os versos de Drummond, n'A Procura da Poesia:

\begin{abstract}
Penetra surdamente no reino das palavras.
Lá estão os poemas que esperam ser escritos.

Estão paralisados, mas não há desespero,

há calma e frescura na superficie intata.

Ei-los, sós e mudos, em estado de dicionário.

(...)
\end{abstract}

$\mathrm{O}$ que deve vir à palavra na poesia é a linguagem ela mesma, ou melhor, uma certa primordialidade da linguagem frente à vida humana que lhe fala/escreve. A poesia é um ofício de linguagem (e talvez não o único) que tem lugar quando, ao tentar capturar a vivência e dela fazer experiência, lança-a, porém, no silêncio. A linguagem fala (e, na experiência heideggeriana, evoca um mundo) sobre o silêncio da vida, quando a vivência daquele que fala/escreve está perdida para a palavra que tenta dizê-la e, como escreveu certa vez Giorgio Agamben, a propósito da poesia provençal: "o poema se torna o lugar de uma ausência que, no entanto, extrai desta ausência a sua específica autoridade" (AGAMBEN, 2007a, p. 213). A tarefa pensante de dizer a própria linguagem através de sua experiência, essa que Heidegger procura levar a cabo pela escuta da poesia, parece pressupor essa separação e isolamento da vivência única e intransferível (e do respectivo sujeito que vivencia/escreve) no silêncio, enquanto a linguagem aí resplandece como "a demora do lógos na archē, ou seja, o estatuto absolutamente primordial da linguagem" (Idem, 2014a, p. 104).

\title{
III
}

Coube a Jeanne Marie Gagnebin a pertinente observação de algumas estratégias retóricas específicas do diálogo platônico, construídas conscientemente com vistas à reivindicação de verdade do discurso filosófico - e muito úteis para o que aqui nos propomos. Essa reivindicação passa pela retomada crítica da palavra mítica e da verdade que nessa palavra se instala, o que torna necessária uma breve caracterização do mito, da experiência arcaica de mito. A eficácia que a palavra mítica desempenha em ser fonte da verdade firmava-se, para o grego antigo, na experiência das Musas como fundamento do canto poético, o que significa: ter experiência de uma palavra suprahumana que, no entanto, concerne aos humanos na medida em que abre, para eles, o acesso à uma Memória Sagrada (Mnemosýne). Essa Memória, que não é um mero empenho humano no registro de eventos passados, mas apresenta-se como "o poder religioso que confere ao verbo poético o estatuto de discurso mágico-religioso", segundo a expressão de Marcel Detienne (2013, p. 16), traz à tona as experiências fundadoras de uma comunidade histórica: o tempo original (cosmogonia) de uma determinada realidade, que veio a ser mediante a intervenção de um ser divino, ou ainda os feitos dos heróis e dos homens célebres etc. As palavras dessa Memória, as Musas, são fonte de ambígua presença, pois ao franquear para o olhar humano a realidade dos 
deuses, precipitam no esquecimento a realidade profana dos mortais - em que cada qual se encontra como indivíduo, temporalmente restringido no limite entre nascimento e morte. Quem é colhido no canto poético como poder supra-humano de revelação da própria dinâmica temporal que constitui a nossa humanidade, tem assim uma experiência da verdade enquanto a-létheia, a i-latência ${ }^{3}$ da realidade fundadora, num duplo jogo de abertura (do sagrado) e fechamento (do profano).

Assim se configurou a experiência poética de Hesíodo, por exemplo, em cuja Teogonia as próprias Musas não apenas inspiram-lhe o canto, como também vêm à fala para dizer-lhe de seus poderes e das realidades que dão a conhecer ao poeta:

\author{
Elas um dia a Hesiodo ensinaram um belo canto \\ Quando pastoreava ovelhas ao pé do Hélicon divino. \\ Esta palavra primeiro disseram-me as Deuses \\ Musas olimpiades, virgens de Zeus porta-égide: \\ "Pastores agrestes, vis infâmias e ventres só, \\ sabemos muitas mentiras dizer símeis aos fatos, \\ e sabemos, se queremos, dar a ouvir revelações".
}

(HESÍODO: TORRANO, 2007, p. 103)

As Musas raptam, capturam a existência do pastor, restrita, por sua própria natureza, à perecibilidade de zóé - ser apenas um ventre (gásteres), uma vida que se consome na necessidade de permanência do indivíduo (nutrição) e da espécie (reprodução). Musa, a palavra poético-religiosa, é a captura da vida e sua consequente elevação à realidade dos deuses, ou, se quisermos: a ambiguidade da presença reveladora que, manifestando-se, recalca no esquecimento a vida meramente mortal, o indivíduo que morre. Dessa forma, a palavra mítica tanto revela quanto esconde, tanto deixa manifesto quanto obscurece e entrava. A ilatência propiciada pela palavra cantada é a dupla experiência de uma perda e um ganho: retida a vida humana na Léthe, no esquecimento acolhedor, filho da Noite Eterna ( $N i x)$, brilha a presença do divino como palavra. A vida e o vivente humano são como mentiras, máscaras e aparências de uma realidade superior - mas mentira aqui não é o falso por oposição ao verdadeiro. Mentira é um nível inferior da própria verdade, em que se movimenta a vida humana em seu sentido profano, do qual as Musas também detêm o saber, e o mantêm cativo no canto ${ }^{4}$.

No momento do seu estabelecimento enquanto discurso, a reivindicação de verdade da filosofia também passa por uma palavra que provém da memória, que quer firmar-se com justeza como vinculação ao passado, voltada, todavia, à condução do futuro. Mas a memória da filosofia não é mais a Memória sagrada, não é o transportarse da vida, ao mesmo tempo suprimida e elevada (ou seja: suspensa), à realidade dos deuses no tempo original. Se em Platão "saber não é outra coisa senão lembrar-se", isso significa, como observa Jean-Pierre Vernant, "escapar ao tempo da vida presente, fugir para longe da terra, voltar à pátria divina da nossa alma, reunir-se a um 'mundo das Ideias' que se opõe ao mundo terrestre com o qual Mnemosyne estabelecia a comunicação" (VERNANT, 1990, p. 127). Na anámnesis platônica realiza-se, com efeito, uma conservação e transformação da relação mítica com o passado imemorial interpretado, do ponto de vista do conhecimento, como a eternidade, a imperecibilidade dos objetos, ou melhor, das realidades concernentes à alma: as ideias. Do ponto de vista da escritura da filosofia, também Platão estabelece uma relação entre a memória e o saber: a despeito de toda a crítica à precariedade da palavra escrita para o conhecimento $^{5}$, a obra platônica possui um momento de obstinada tentativa de salvar a memória de seu mestre Sócrates, injustamente (a seu ver) condenado à morte pelo tribunal de Atenas. Nesse ponto insere-se a contribuição de Gagnebin, que percebe uma 
dupla alteração da palavra filosófica em relação à palavra poética: tanto em sua relação com a memória como, em decorrência disso, em sua relação com a verdade. "A voz do filósofo não pode mais reivindicar para si a função sagrada da ligação com o passado e com as origens, como podia o poeta. Deve, sim, propor e defender uma outra interpretação para um episódio singular" (GAGNEBIN, 2009, p. 197). Narrar com veracidade esse evento singular (a morte de Sócrates), de modo a extravasar o simples relato e construir um testemunho, não apenas de Sócrates, mas também da própria filosofia - tal parece ser a reivindicação de verdade da prosa platônica que, ao nascer como memória de Sócrates, transforma-se em memória da filosofia como atividade dialógica, como conversa. E não estranha o registro de Platão no Fédon (61a), em que Sócrates declara a filosofia como a "mais alta música" - em que se deve ler: a mais alta arte da Musa, ou a Musa mais elevada, a palavra mais forte e mais verdadeira ${ }^{6}$.

E contudo, nem essa força nem essa verdade poderiam fazer-se presente caso a prosa platônica estabelecesse a si própria como relato individual, percepção subjetiva, opinião e comentário sobre a vida de Sócrates - como é o caso, por exemplo, dos escritos de Xenofonte. Nesse ponto, uma estratégia retórica na escritura foi fundamental para a construção do testemunho filosófico que constitui o diálogo platônico: a "denegação sistemática do possível caráter autobiográfico dos diálogos" (GAGNEBIN, 2009, p. 198). Na experiência da linguagem que Platão leva a termo - qual seja: construir a memória de Sócrates como testemunho da filosofia, na intersecção entre palavra e memória já trazida pela experiência mítica - Platão ele mesmo está retido, suspenso em seu texto. Platão retira-se de seus textos assim como, tacitamente, exclui a si mesmo da cena da morte de Sócrates: "Platão, creio, estava doente" (Fédon, 59a)7.

\section{IV}

Do muito que possa ser escrito sobre a notável ausência do "autor-Platão" em suas obras ${ }^{8}$ (e que certamente não é sem importância), gostaríamos de reter o seguinte comentário de Gagnebin, que nos leva mais diretamente ao ponto que aqui nos interessa: a intersecção entre elisão do autor e verdade do discurso:

Ele [Platão] não faz questão de possuir seus pensamentos, de ser o senhor dos seus lógoi, de ser o proprietário exclusivo de seus livros e de seus escritos (como sustenta toda a crítica de Platão à escrita, ou melhor, à relação fetichista que o escritor pode ter com seus escritos). Fundamentalmente, portanto, o filósofo não é o sujeito soberano de seu discurso; seria muito mais o próprio lógos que o move e não o sujeitoautor particular que se apodera e se assenhora do lógos (GAGNEGIN, 2009, p. 199, colchetes nossos).

Há em Platão, assim como na forma arcaica da poesia (talvez mesmo em toda forma de discurso com pretensões à verdade) essa duplicidade de movimento em que a verdade do discurso ganha luminosidade no obscurecimento, na retenção da figura de seu autor. Gagnebin oferece aqui uma nova perspectiva pela qual possa ser encarado o problema da frágil relação da palavra escrita com o saber e a verdade, tal como Platão o apresenta: frágil não somente por afrouxar o arco teso da Memória, transmitida vivamente através da oralidade, mas também por reivindicar autonomia, pretender uma vida independente da vida que escreve, de quem seja o "pai" da escritura9.

Se, por um lado, a fixidez que caracteriza o discurso escrito pode tornar caduca essa pretensão da fala em se ver livre do falante (pois quando a escritura "é agressivamente criticada, injustamente vilipendiada, ela tem sempre a necessidade da segurança de seu pai [isto é, daquele que escreve], pois é, estando sozinha, incapaz de se defender e de levar segurança a si mesma"10), por outro lado, toda tentativa de apresentação da verdade por escrito realiza a retenção de seu autor enquanto sujeito da fala - portanto, a obstrução do autor como senhor e pai do lógos, cuja existência pública exige uma resposta (que o discurso mesmo, enquanto escrito, não pode dar), 
mas que não dá ao seu "pai" qualquer privilégio de tomar a palavra e ser o único a responder por ele. $\mathrm{O}$ autor é pai de um filho pródigo, que, por assim dizer, "caiu na vida", e não tem qualquer intenção de voltar para casa. Em público, na vida pública, o discurso escrito torna-se sempre outro ao ser percorrido em cada leitura - sem que o "indivíduo-autor" possa reivindicar a mesmidade daquela fala, que partiu de si. Esse 116 ponto preocupa particularmente Platão: "Ora, nossa mais segura garantia é nada escrever, mas aprender de cor; não é possível, com efeito, evitar que aquilo que fora escrito não seja exposto a semelhante acidente" [qual seja: "vir a cair nos ouvidos de gente indigna de lhes entender"] (Carta II, 314 b-c - PLATÃO, 1950, p. 1172, grifo e trad. nossos). Se Platão chega a escrever, nessa mesma carta a Dionísio de Siracusa, que simplesmente "não existe, de Platão, tratado que concirna a essas questões", e que tudo que delas se pode ler em seus diálogos "é de Sócrates, quando esse estava no esplendor da juventude", isso talvez possa ser compreendido, em conjunto, da seguinte forma: escrever é o mais alto risco, posto que exige de nós, não a tentativa de nos colocarmos na escrita mas, ao contrário, o gesto de sairmos dela para o silêncio, esvaziar o discurso de nós mesmos, do que em nós é mera vivência. Se bem quisermos ser donos do que pensamos, guardemo-lo conosco; mas se o escrevemos, que o deixemos, de certa forma. Novamente - não há Platão nos diálogos de Platão. Ou ainda: Platão é, em seus diálogos, apenas a vida que ficou suspensa, retida nas palavras das quais faz a experiência, obscurecida pela luz da verdade que na sua linguagem ensaia expressar-se.

Se a filosofia ousa escrever, tal como o tem feito a dois milênios e meio; se ela ousa sair da segurança da pura Memória e literalmente correr o risco da escrita, isso significa que nela, assim como na poesia, o autor se põe em jogo na escrita, deixa em suspenso as próprias vivências na pretensão de verdade de seu discurso. $\mathrm{O}$ fenômeno conhecido na teoria literária como a "morte do autor", que ganhou relevo em muitas análises textuais em literatura a partir do século passado, pode não se tratar simplesmente de um fait accompli da escritura, de toda e qualquer forma de texto - ou mesmo a reação contemporânea à figura moderna do autor, objeto no qual a crítica literária julgava encontrar a "explicação" do texto"1. Há um tratamento da linguagem que tem em vista a elaboração e a transmissão de um conceito de verdade - ou melhor, há uma experiência com a linguagem que, de alguma forma, rearticula e reapresenta, isto é, dá a ver a realidade desde a perspectiva de seus pontos fundamentais, de sua dinâmica de constituição. Uma experiência dessa ordem é a poesia, por exemplo, como palavra mítica, como poder supra-humano que suspende a vida mortal na revelação das realidades imortais. Uma outra experiência assim caracterizada é a filosofia, que em Platão mostra-se como exercício dialógico - e por isso mesmo revela-se drama, ação, teatro. Que não se nega a ser escrita e assim transmitida, mas desenha um lugar de silêncio para aquela vida que a escreve, no ato mesmo da escrita. De sorte que fazer filosofia é mover-se na ambiguidade de uma vida que, se por um lado compromete-se de forma quase unilateral com aquela "frequente coexistência junto à coisa ela mesma", de que Platão fala na Carta VII (341b), doutro lado precisa abrir mão do achado de sua busca, do fruto mesmo dessa coexistência, uma vez que esse venha a se fazer escrito. Por isso, por não poder estar o autor mesmo presente na palavra que abre a sua experiência com o pensamento para os outros, a filosofia não poderia ser jamais ensinada como uma doutrina. Se ela, escrita e reescrita, ainda segue como "uma luz que brota na alma como quando faísca a chama, e doravante nutre-se a si mesma" (escreve Platão na sequência da Carta VII), sua continuidade eminentemente individual carece, de uma parte, dos textos que a tradição lega, e doutra parte, da ausência de seus autores em cada um desses mesmos textos, do lugar vazio em que cada leitor neles se arrisca.

\section{V}

Aqui se reúnem as duas linhas mestras pelas quais o presente texto fora guiado, convertendo-se em um quadrado de termos parelhos: de um lado, a poesia como palavra 
mítica, a vida suspensa na assunção da realidade dos deuses, e a palavra filosófica que quer ser memória de si mesma e da tradição que a acompanha; do outro lado, a poesia como palavra que quer ser memória de si mesma e da tradição que a acompanha no tempo da ausência dos deuses, e a palavra filosófica que experimenta nessa forma da poesia o fundamento infundado da linguagem:

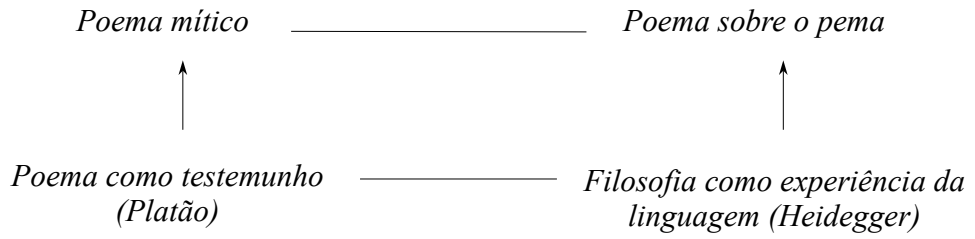

Caso algo seja verdadeiro nessa simetria, sem dúvida ainda muito grosseira, teríamos de reconhecer que a filosofia atua, em ambos os casos, como um modo de interceptação de um dizer que lhe advém como legado, ou ainda, que a própria filosofia é sempre já algo como uma experiência da linguagem (ponto insistente de nosso texto, e ao qual ainda retornaremos). E é exatamente como experiência de uma linguagem herdada que a filosofia chega a realizar-se como modo eminente de exposição da verdade: ela guarda, reelabora e traz à tona os móbiles fundamentais da existência humana contidos nos discursos que, estabelecidos como tradição, abrem um acesso à realidade para o homem. Na filosofia, o pensamento alcança a linguagem que, por sua vez, já abriu (em sua forma poética) um mundo tal que nele o humano venha a habitar. Essa afirmação leva-nos a uma contração que converte nosso quadrado inicial em um triângulo:

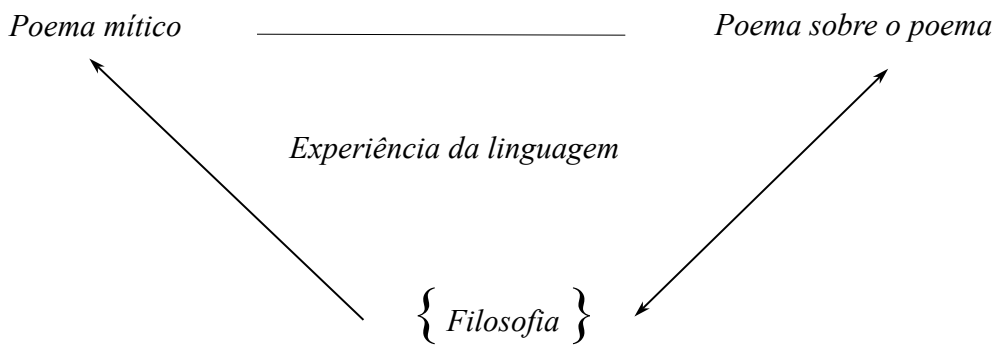

A filosofia reflete, dobra-se sobre a palavra mítica de um modo que, ao mesmo tempo, conserva e transforma, salva e recria o que nela se diz: as "formas fundamentais de o mundo de todos os dias mostrar-se como uma totalidade organizada em que é possível a vida em geral e mais especificamente a existência humana" (TORRANO, 2013, p. 25); tais formas fundamentais são, para a mitologia, os deuses, e para a filosofia platônica, os paradigmas, as formas ou ideias inteligíveis. A poesia mítica antecede a filosofia, fornece-lhe o material mesmo de que se alimenta sua experiência com a linguagem e existe independente do que ela lhe faça. Já no poema sobre o poema, em que a poesia faz experiência de si mesma como pura linguagem, não só se fornece um material para o discurso filosófico, como a poesia mesma busca na filosofia as fontes de seu dizer: a ausência dos deuses é um fenômeno histórico da ausência do fundamento supra-humano da linguagem, em cuja captura o humano vem a reconhecerse como tal, elevando-se acima da mera vida natural. Sobre esse pano de fundo comum 
da ausência de um fundamento, o discurso circula entre a filosofia e a poesia como exposição de si mesmo no silenciamento da vida - uma sutil, mas fundamental diferença em relação ao mito, no qual a vida é suspensa para a revelação, não do discurso ele mesmo, mas de seu elemento sustentador que transcende a vida humana: a realidade dos deuses.

Filosofia e poesia são, como polos entre os quais a palavra transita, experiência não daquilo que a linguagem aponta ou denota no mundo, mas experiência da linguagem mesma, ou ainda: elas são o esforço de trazer a linguagem a si mesma, de fazer com que ela possa dizer-se - tal como vimos ser o empreendimento heideggeriano. Também vimos que o ponto cego desse empreendimento (e, portanto, da filosofia e da poesia) é: aquilo que se quer dizer (a linguagem ela mesma) é silêncio; o elemento de todo dizer é um (ainda)não-dito que articula todos os modos possíveis de dizer; ir ao limite da linguagem seria lançar-se contra um inefável. Quando a filosofia vai colher, em uma experiência com a palavra poética, um modo de expor a verdade, a palavra cala a vida que escreve. Isso não significa dizer, necessariamente, que o autor está morto. Preferimos dizer, com Agamben (2007b, p. 58), que "pôr-se como autor significa ocupar o lugar de um morto. Existe um sujeito-autor, e, no entanto, ele se atesta unicamente por meio dos sinais de sua ausência”.

\section{VI}

Quais são esses sinais que atestam a ausência pela qual se manifesta o autor? Poder-se-ia pensar que se trata da própria escrita, compreendida como rastro, como marca deixada para trás por alguém que ali esteve, como uma espécie de presença do autor ausente ${ }^{12}$. Mas há uma diferença essencial entre a palavra e o rastro (em sentido amplo), que Jeanne Marie Gagnebin nos aponta: "Rigorosamente falando, rastros não são criados - como são os outros signos culturais e linguísticos -, mas sim deixados ou esquecidos" (GAGNEBIN, 2009, p. 113). Entre os rastros e as palavras (que são, ambos, formas diferentes de signos), há a fundamental diferença da intenção, que aqui entendemos como o endereçamento da palavra a outrem - enquanto o rastro é vestígio não dirigido, mas simplesmente perdido ou esquecido. Por isso a palavra escrita não suprime a vida que escreve por ser um rastro aleatoriamente deixado para trás; para as formas de discurso que aqui consideramos, a filosofia e a poesia, escrever não é somente deixar um rastro, mas realizar um gesto. No ensaio $O$ Autor como Gesto, em que Agamben aborda a conferência $O$ que é um Autor?, de Foucault, vamos buscar o que compreendemos, aqui, por gesto: "Se chamarmos de gesto o que continua inexpresso em cada ato de expressão, poderíamos afirmar então que, exatamente como o infame, o autor está presente no texto apenas em um gesto, que possibilita a expressão na mesma medida em que nela instala um vazio central" (AGAMBEN, 2007b, p. 59). O poeta e o filósofo deixam-se em suspenso na escrita (da poesia e da filosofia), não como quem abandona (por vezes à revelia) um rastro pelo caminho, mas como um gesto que deixa na escrita um lugar vazio a ser ocupado. A palavra, diferente do rastro, comporta uma intenção, é dirigida a outrem, ela interpela - quando a vida que escreve se pôs em jogo nela de tal forma que abre mão de sua propriedade. Por isso a vida jogada na obra (aqui, as obras da linguagem, da palavra) e ali suspensa é a condição de sua transmissão, de seu legado:

O autor marca o ponto em que uma vida foi jogada na obra. Jogada, não expressa; jogada, não realizada. Por isso o autor nada pode fazer além de continuar, na obra, não realizado e não dito. Ele é o ilegível que torna possível a leitura, o vazio lendário de que procedem a escritura e o discurso (Idem, ibidem, p. 61).

Trazemos essa contribuição do ensaio de Agamben ao final de nosso texto para que se possa pensar a palavra da poesia e a da filosofia, na qualidade de gesto de uma vida ausente (ou a fala da linguagem no silêncio da vida), como formas de uma palavra 
ética. De fato, Agamben nos indica que uma vida "ética" "não é a vida que simplesmente se submete à lei moral, mas a que aceita, irrevogavelmente e sem reservas, pôr-se em jogo nos seus gestos" (Idem, ibidem). A vida que se põe em jogo no gesto da escrita, tanto na poesia como na filosofia, suspende a si mesma na palavra enquanto a transforma em um convite, que sempre chama a outrem para dela tomar partido. Poesia e filosofia têm a outrem como destinatário, são palavras que nascem para ser partilhadas porque quem as escreve, delas mesmas se evade, esvazia-as de suas vivências; a autonomia da linguagem frente à vida humana (o que também pode ser expresso como o fundo silencioso de toda linguagem) é apenas a necessária superfície da palavra que quer sempre voltar a ser humana, de cada um que nela toma parte. E em todo aquele que toma parte da palavra (pensada e poetizada) a vida humana re-emerge, plena, do interior da linguagem.

\section{REFERÊNCIAS:}

AGAMBEN, Giorgio. Estâncias: A palavra e o fantasma na cultura ocidental. Trad. Selvino J. Assmann. Belo Horizonte: UFMG, 2007a.

"O Autor como Gesto". In: Profanações. Trad. Selvino J. Assmann. São Paulo: Boitempo, 2007b.

. Categorias Italianas: Estudos de poética e de literatura. Trad. Carlos Eduardo Schmidt Capela e Vinícius Nicastro Honesko. Florianópolis: UFSC, 2014.

BARTHES, Roland. "La Mort de l'Auteur". In: Éditions du Seuil, 1984.

DETIENNE, Marcel. Mestres da Verdade na Grécia Arcaica. Trad. Ivone C. Benedetti. São Paulo: Martins Fontes, 2013.

DRUMMOND, Carlos. Antologia Poética. São Paulo: Abril Cultural, 1982.

GADAMER, Hans-Georg. Verdade e Método I: Traços fundamentais de uma hermenêtica filosófica. Trad. Fávio Paulo Meurer, com rev. de Enio Paulo Giachini. Petrópolis: Vozes, 2004.

GAGNEBIN, Jeanne Marie. Lembrar escrever esquecer. São Paulo: Editora 34, 2009

HEIDEGGER, Martin. A Caminho da Linguagem. Trad. Márcia Cavalcante Schuback. Petrópolis: Vozes, 2008.

"Para quê Poetas?" In: Caminhos de Floresta. Trad. Bernhard Sylla e Vítor Moura. Lisboa: Calouste Gulbenkian, 2012.

. Explicações da Poesia de Hölderlin. Trad. Cláudia Pellegrini Drucker. Brasília: UnB, 2013.

Introdução à Metafísica. Trad. Emmanuel Carneiro Leão. 4.ed. Rio de Janeiro: Tempo Brasileiro, 1999.

HESÍODO; TORRANO, Jaa. Teogonia: A origem dos deuses. São Paulo: Iluminuras, 2007.

PLATÃO. CEuvres Complètes. Trad. et notes de Léon Robin. Paris: Les Belles-Lettres, 1950.

TORRANO, Jaa. O Pensamento Mítico no Horizonte de Platão. Belo Horizonte: Annablume, 2013.

VERNANT, Jean-Pierre. “Aspectos míticos da memória”. In: os Gregos. Trad. Haigakuch Sarian. São Paulo: Paz e Terra, 1990.

\section{NOTAS}

1 "Milagre da distância e da quimera/ Trouxe para a margem de minha terra,// Na dureza até a cinzenta norna/ Encontrei o nome em sua fonte-borda -// Podendo nisso prendê-lo com peso e decisão/ Agora ele brota e brilha na região...// Outrora eu ansiava por boa travessia/ Com uma jóia delicada e rica.// Depois de longa procura, ela me dá a notícia:/ 'Assim aqui nada repousa sobre razão profunda'.// Nisso de minhas mãos escapou/ E 
minha terra nunca um tesouro encontrou...// Triste assim eu aprendi a renunciar:/ Nenhuma coisa que seja onde a palavra faltar." (GEORGE, S. apud HEIDEGGER, M., 2008, p. 174).

2 A distinção aqui esboçada entre experiência e vivência é totalmente insuficiente do ponto de vista conceitual, e a necessidade de clarificação rigorosa de ambos os conceitos excederia completamente o escopo do presente trabalho - sobretudo devido à longa história que ambos os termos guardam na tradição filosófica. Remeto o leitor, no entanto, para duas compreensões que norteiam a presente distinção: 1) a respeito da noção de experiência, a já citada conferência de Heidegger sobre "A Essência da Linguagem", I (HEIDEGGER, 2008, p. 121ss); 2) sobre a noção de vivência, a primeira parte de Verdade e Método I, de Hans-Georg Gadamer, item 1.2.2: "A estética do gênio e o conceito de vivência" (GADAMER, 2004, p. 99ss).

3 Tradução de Jaa Torrano (2013, p. 27).

4 Para a relação entre verdade e mentira, como as duas dobras da mesma ilatência (alétheia), conferir o ensaio de Jaa Torrano "Mito e Verdade em Hesíodo e Platão" (TORRANO, 2013, p. 29-54), do qual a presente análise é, em grande parte, devedora.

5 Cf. sobretudo: Fedro, 274 b ss; Carta II, 314 c; Carta VII, 341 b-c. Esses trechos serão objeto de nossa consideração mais adiante.

6 Cf. também: Rep. VIII, 548b, no qual "a verdadeira Musa (é) aquela que acompanha os raciocínios (logoí) e a filosofia” (PLATÃO, 1975, p. 1145, trad. nossa).

7 Essa citação é também o título do ensaio de Jeanne Marie Gagnebin.

8 Por exemplo, o artigo de Luísa Severo, no qual a autora dá prosseguimento ao texto de Jeanne Marie Gagnebin, investigando o "parentesco entre o gesto platônico da elisão de si mesmo enquanto autor e o gesto do tragediógrafo de ausentar-se de sua própria cena" Cf.: SEVERO, Luísa. "Mas, cidadãos de Atenas, Platão, aqui presente..." Platão tragicômico. In: O que nos faz pensar. Rio de Janeiro, no 34, p. 109-124, mar. 2014.

9 A respeito das muitas conotações do termo "pai" em relação ao lógos e à escritura, cf.: DERRIDA, Jacques. A Farmácia de Platão. Trad. Rogério da Costa. São Paulo: Iluminuras, 2005, p. 23-34 - Cap. 2: "O Pai do Lógos".

10 Fedro, 275e (PLATÃO, 1950, p. 76, colchetes e trad. nossos).

11 Roland Barthes, em seu ensaio "A Morte do Autor" (1967), embora atente para o fato de que um uso específico do discurso ("desde o momento em que um fato é contado para fins intransitivos, e não para agir diretamente sobre o real") pode produzir o "afastamento do autor", parece crer que esse afastamento (ou "distanciamento", ou simplesmente "morte") é uma reação contemporânea à invenção moderna da figura do autor - pois, diferentemente dos antigos, "o escritor moderno nasce ao mesmo tempo que o seu texto; ele não está de modo algum provido de um ser que precederia ou excederia a sua escrita, não é em nada o sujeito do qual o seu livro seria o predicado; não há outro tempo que aquele da enunciação, e todo texto é escrito eternamente aqui e agora" (cf. BARTHES, 1984, p. 61-7, trad. nossa).

12 É nesse sentido que Barthes escreve, no ensaio de 1967 sobre a morte do autor (cf. nota anterior), "que a escrita é a destruição de toda voz, de toda origem", ou seja, a letra é, como marca impressa e rastro deixado para trás, o sinal de uma presença passada, suprimida ou não encontrável. 